FURTHER OBSERVATIONS UPON BOMBYX CUNEA, DRURY, ETC.

BY THE REV. THOMAS W. FYLES, SOUTH QUEBEC.

To make my way clear I beg to state the objects I had in view in writing the article that appeared under my name in the number of the Canadian Entomologist for last May. They were these :

I.- - To establish the identity of the Spilosoma Antigone of Strecker with the Spilosona congrua of Walker.

II.-To show that Dr. Riley's series of wings in Fig. 87, Packard's Forest Insects, does not afford a proof conclusive that cunea, textor, punctata and punctatissima are one and the same species of insect.

III.-To bring into notice a Spilosoma which answers to the figure given by Drury of his Bombyx cunea.

I.-It is admitted that Antigone and congrua are identical. I need not say anything more on that point.

II.-I have always looked upon Riley's series of wing-figures with distrust-much as I should regard a catena brought forward by a controvertialist to support an erroneous opinion; and, in the paper I have mentioned, I endeavoured to show the weakness of his position by stating that a like series of wing-figures could be taken from specimens of moths raised from "black ground-feeding larvæ." It has been said "there is no doubt at all of the identity of all these forms," and if a positive assertion could have settled the matter, it would have been settled; but a chain is not stronger than its weakest links, and Sir James Smith was not sure of the identity of punctatissima with Drury's congrua, and Dr. Ottolengui gives voice to a doubt, which others beside himself have felt, and says: "Is it possible that the immaculate and the spotted forms of cunea may be distinct?" (By these "forms" I understand him to mean punctatissima and textor.)

Smith and Abbot give us a picture of their Phalcena punctatissima. There is an irregularly spotted male insect, a spotless female, and a larva feeding upon a sprig of mulberry. Quite a fancy sketch! And this is the description appended :

"Ph. Bombyx elinguis, alis deflexis corporeque niveis nigro punctatis, thorace utrinque lunula nigra."

And under this is a note (the italics are mine) : 
"Whether this be the cunea of Mr. Drury or not, it deserves a more expressive, or rather a less erroneous, name. The character above given applies to the male only, the female being entirely white."

Now, Dr. Dyar tells us that "Walker knew cunea, Drury" (CAN. ENT., v. XXXI., p. I55), very well. What does Walker say about the female of the species? This is what he says: "Female-Hind wings with some brown submarginal spots."

There is no warrant whatever for speaking of an immaculate cunea, Drury-whether male or female. Drury neither figured nor described such an insect.

I hope it will be understood that when I have spoken of cunea I have meant Drury's cunea-not the insects that of late have been erroneously called by that name. When I have spoken of moths from fall webworms, I have designated them as such, or I have used the term given by Harris for the northern immaculate insect, and the term given by Smith and Abbot for the southern spotted insect.

Hyphantria textor, Harris, and Phalana punctatissima, S. and A., are supposed to be (though Harris had no idea that they were) seasonal varieties of one and the same species of moth-a moth that comes from the fall webworm.

In Canada we have only one brood of this species in the year, but southward there are two generations of it. Thus Dr. Wm. Saunders writes :

"In the northern United States and Canada there is only one brood of this insect in the season, but in the south it is frequently doublebrooded, the first brood of the larvæ appearing in June, the second in August."-Insects Injurious to Fruits, p. 73.

And Dr. L. O. Howard writes :

"In the District of Columbia and north to New York City there are two generations annually." $\quad * \quad * \quad * \quad * \quad * \quad * \quad *$

"The caterpillars of the second generation begin to make their appearance in force in August."-Farmers' Bulletin No. 99, p. 20.

It is, I presume, the moths from this second generation that Dr. Ottolengui refers to in his "Contribution, etc.," in the December number of the Canadian Entomologist, pp. 358-9.

With his remarks, as to the profuse spottedness of these early moths, agree, in part, the words of Mr. James S. Johnson, who wrote from Frankford, Pennsylvania, in August, r 880 , and said : 
"Hyphantria textor (Harris) made its appearance in this locality on May roth, and from that date to the $\mathrm{r} 3^{\text {th }}$ I captured 53 \& examples and ro $? . "$

"On June $\mathrm{I}$ th the second brood appeared, and in three days I took $4 \mathrm{I}$ \& and Io $\% . "$

"In the first brood every male had the black spots on the primaries, from a single spot on each wing to almost covered, and in some examples a spot on the secondaries. In the second brood all were bright, not an example with the least trace of a mark, the females in both broods entirely white."-Can. ENT., vol. XIII., p. 18.

The italics in the above quotation are mine.

Mr. Johnson asked these questions: "Has the first brood, or that which remains over winter only, the black spots? or does $H$. textor alternate?"

As far as my knowledge extends, these questions have not been answered. No one has come forward to say, "From eggs laid by $H$. textor I have raised a brood of $H$. punctatissima," or, vice versa, "From eggs laid by $H$. punctatissima I have raised a brood of $H$. textor." If I am mistaken in this I shall be glad if someone will tell me when and where and by whom the statement has been made.

As regards our northern examples of textor: I have ten moths (males and females) that I have raised at different times from fall webworms. Not one of them has any appearance of a spot at the base of the second fork of the median nerve, such as is shown in " $f$ " of Riley's "Fig. 86," in Packard"s Forest Insects, and " $a$ " in "Fig. 87 " of the same work.

The dimensions of the moths that come from fall webworms have been given as follows:

In the New England States-One inch and a quarter to one inch and three-eighths- Harris, Ins. Inj. to Veg., p. $35^{8}$.

In Canada-One inch and a quarter-Saunders, Ins. Inj. to Fruits, p. 73 .

In the Southern States-One inch and one-tenth-Howard, Farmers' Bulletin No. 99 (by figures), pp. 24 and 26.

We must accept the dimensions given by these authorities as reliable. From them it appears that the Southern specimens of moths from fall webworms are smaller than the rest. What the very large moths, that have 
been mistaken for and associated with $H$. textor, really are must be determined by further careful breeding.

III.-American Entomological literature is rich in synonyms, and Dr. Dyar seems ambitious to add another to the list (see his "Correction" in the January number of the Canadian Entomologist).

The following is the description of Spilosoma prima, Slosson :

"Size of S. virginica, but a stouter insect, body heavier and shorter, scarcely reaching anal angle of secondaries. Primaries sordid white, stained with ochreous, especially along costa and inner margin, and with scattered dots of dark brown. These are arranged almost exactly as in some specimens of the form of $\mathrm{H}$. textor, Harris, known as cunea and punctata. The dots are much heavier and more distinct on costa, and there is a submarginal line very plainly indicated and composed of geminate dots on the venules. Secondaries sordid white. Abdomen thickly clothed with white hairs, through which can be seen the yellow of the body, with dorsal row of black spots. Palpi, coxa and tibia very dark smoky brown, almost black."-Ent. Amer., V., 40 (1889).

And these are some of the points in which this insect seems to differ from the Spilosoma taken at Quebec and believed to be the Bombyx cunea of Drury:

S. PRIMA, Slosson.

Size of S. virginica.

Stouter than Virginica.

A submarginal line of geminate dots on primaries.

Secondaries sordid white (no mention of spots).

J)orsal row of black spots on abdomen.

Tibiæ very dark smoky brown.
The Quebec Insect.

Smaller than $S$. virginica.

Not so stout as Virginica.

A submarginal line of dashes and streaks on primaries.

Secondaries much spotted, as in Drury's figure.

Five rows of black spots on abdomen (Drury's figure shows dorsal and side lines. The under side of the insect is not figured).

Tibiæ white on the outside, dark brown on the inner.

But supposing $S$. prima, Slosson, were shown to be identical with the insect I have described, that would not prove that Phalcena punctatissima, S. and A., is one with B. cunea, Drury : it would rather indicate that we have had one more synonym in our literature than we have been aware of. 
I do not know that I can say any more on the subjects that we have had under discussion. I trust that I have written with befitting modesty, and that I have given the reasors for my statements with sufficient clearness. After weighing all that has been written, I am convinced that Hyphantria textor, Harris, is not one and the same with Bombyx cunea, Drury, and that the insect I have described as cunea more closely corresponds to Drury's figure than any other moth, or any figure or description that has come under my notice.

\section{NOTE ON CYANIRIS PSEUDARGIOLUS OF BOISDUVAL AND LE CONTE.}

By ARThUR G. BUTLER, PH. D., BRITISH MUSEUM, LONDON, ENGLAND.

In 1 782, Cramer described and figured a Cyaniris (Pl. CCLXX., figs. D, E), and incorrectly gave the Cape of Good Hope as its locality.

In his "Rhopalocera Africa Australis," Mr. Trimen described the species from a single example labelled " $\mathrm{S}$. Africa" in the British Museum collection, and stated that this was the only example he had seen. In his later work this species is ignored, Mr. Trimen having evidently satisfied himself that it never came from any part of Africa. On looking up the authority for the locality of the specimen mentioned by Trimen in our oldest " Register of Accessions," I find it entered as " P. Ladon, Cram., n., S. Africa?" the locality having evidently been entered on Cramer's authority.

As a matter of fact, Cramer's insect is undoubtedly Cyaniris pseudargiolus, which it necessarily supersedes, and our reputed African example is a large specimen of the form marginata, rather less suffused than usual on the under surface.

It is always inconvenient to alter the names of well-known and abundant species, but under the circumstances I do not see how it can be avoided in the present instance : it will perhaps have one advantage as $C$. pseudargiolus is not half so nearly related to $C$. argiolus as it is to the Sikhim species, $C$. dilectus, an inappropriate name is suppressed.

\section{A NEW OAK-GALL FROM NEW MEXICO.}

BY T. D. A. COCKERELL, N. M. AGR. EXP. STA.

Dryophanta Porterce, n. sp. $-q$. Length, $2 \frac{x}{3} \mathrm{~mm}$. ; very dark brown ; cheeks, tibiæ more or less, tarsi, and antennæ except tips, clear ferruginous ; smooth and shining, parapsidal grooves distinct; head transversely quadrate, broader than long; antennæ i 3 -jointed, I 3 a little longer than I I and I 2, 3 about a third longer than 4 (3 about $200 \mu, 4$ about I $50 \mu$, I 3 about $180 \mu)$; scutellum prominent; ovipositor rather long, ferruginous, its apical portion with six rings, counting the apex as one; 